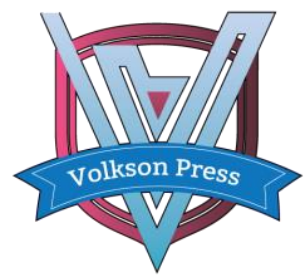

Contents List available at VOLKSON PRESS

New Materials and Intelligent Manufacturing (NMIM) DOI : http://doi.org/10.26480/icnmim.01.2018. 312.314

Journal Homepage: https://topicsonchemeng.org.my/

ISBN: 978-1-948012-12-6

\title{
INHIBITORY EFFECT AND ENZYMOLYSIS KINETICS OF LENTINAN ON A-GLUCOSIDASE
}

\author{
Meifu Wu, Hongli Zhou* \\ School of Chemistry and Pharmaceutical Engineering, Jilin Institute of Chemical Technology, Jilin 132022, China. \\ *Corresponding Author Email: zhl67@126.com
}

This is an open access article distributed under the Creative Commons Attribution License, which permits unrestricted use, distribution, and reproduction in any medium, provided the original work is properly cited.

\section{ARTICLE DETAILS}

Article History:

Received 26 June 2018

Accepted 2 July 2018

Available online 1 August 2018

\section{ABSTRACT}

Objective: To study the inhibitory activity and enzymolysis kinetics of lentinan on $\alpha$-glucosidase. Methods: The enzyme-agent screening model was used to investigate the optimal conditions of $\alpha$-glucosidase action. In vitro enzyme kinetics was studied by changing the substrate concentration, reaction time, $\mathrm{pH}$ conditions and temperature. Results: The optimal reaction conditions of $\alpha$-glucosidase were reaction time $120 \mathrm{~min}$, reaction temperature $50^{\circ} \mathrm{C}$, buffer $\mathrm{pH} 6.0$, concentration of substrate PNPG $0.1089 \mathrm{~mol} / \mathrm{L}$. Conclusion: $1 \mathrm{~g} / \mathrm{L}$ concentration of lentinan has good inhibitory activity against $\alpha$-glucosidase, and the inhibitory effect of lentinan is competitive inhibition.

KEYWORDS

Lentinan, $\alpha$-glucosidase, enzymolysis kinetics

\section{INTRODUCTION}

Edible fungi are widely used in folk, and their active substances can promote the secretion of insulin and related hormones, so that the function of liver, pancreas and other organs of diabetic patients can return to normal [1]. The study found that Lentinan (LTN) is a polysaccharide isolated from the fruiting body of Lentinus edodesis, which an important immunomodulator, has a significant inhibition of tumor, lowering blood sugar and anti-virus, etc.It is one of the hotspots of research at domestic and abroad in recent years [2,3]

Diabetes mellitus is a chronic metabolic disorder, and its treatment must be based on dietary therapy. Reasonable dietary therapy can make drug treatment more effective [4]. Type II diabetes accounts for more than $90 \%$ of all cases of diabetes [5]. The $\alpha$-glycosidase is a type of oligosaccharides, mainly distributed in the brush like edge of the small intestinal epithelial villi, and can degrade a series of oligosaccharides, including sucrose, maltose and lactose. The $\alpha$-glycosidase mainly breaks down the $\alpha-1,4$ glycosidic bond of oligosaccharide non-reductive end [6]. The $\alpha-$ glycosidase inhibition inhibits glucoside hydrolase, inhibits the decomposition of polysaccharides and sucrose, inhibits the absorption of carbohydrates in the upper intestine, slows down the increase of postprandial blood glucose, and prevents cardiovascular diseases caused by blood glucose fluctuations. It can also be combined with insulin in the treatment of type I diabetes in order to reduce the dosage of insulin and stabilize blood glucose, and to alleviate hyperinsulinemia [7,8]. In this paper, the inhibition of letinous edodes polysaccharide on alpha glucosidase was studied, and a new way to treat diabetes was exploited.

\section{EXPERIMENTAL REAGENTS AND EQUIPMENT}

Lentinan, Shanghai source leaf Biological Technology Co., Ltd.; PNPG, Beijing Bellingway Technology Co., Ltd.; $\alpha$-glucosidase, Aladdin reagent; phenol, Tianjin Northern Medical chemical reagent factory; concentrated sulfuric acid and phosphoric acid, Tianjin Chemical Reagent Factory; sodium carbonate, Tianjin Tanggu Peng Da chemical, the above reagents are all analytically pure.

The preparation of phosphate buffer solution of $\mathrm{pH} 6.8 ; 0.1245$ mol/LPNPG solution; Preparation of $1 \mathrm{~mol} / \mathrm{L}$ sodium carbonate solution; $\alpha$-glucosidase; $2 \mathrm{~g} / \mathrm{L}$ letinous edodes polysaccharide solution; Preparation of $1 \mathrm{~g} / \mathrm{L}$ acarbose standard solution [9].

\section{EXPERIMENTAL METHODS}

3.1 Determination of enzyme inhibitory activity and calculation of inhibition rate of enzyme activity

Using PNPG as a substrate, $\alpha$-glucosidase catalyzed the hydrolysis of PNPG and generated nitrophenol (PNP) to change the PNP content of the reaction system within a certain period of time to calculate the inhibition of lentinan to $\alpha$-glucosidase active [10]. Reaction system: $200 \mu \mathrm{L}$ of pH 6.8 phosphate buffer solution was added first, then $100 \mu \mathrm{L}$ of $30000 \mathrm{U} / \mathrm{L} \alpha-$ glucosidase was added. Sample solutions of different concentrations were shaken and mixed. After reacting at $37^{\circ} \mathrm{C}$ for $20 \mathrm{~min}, 75 \mu \mathrm{L}$ was added. The $0.1245 \mathrm{~mol} / \mathrm{L}$ PNPG was began. After turbulence mixing, the reaction was continued at $45^{\circ} \mathrm{C}$ for $1 \mathrm{~h}$ followed by the addition of $1 \mathrm{~mol} / \mathrm{L}$ sodium carbonate solution to stop the reaction. Finally, the OD value was measured at $405 \mathrm{~nm}$ with an ultraviolet-visible.

The experiment was divided into three groups: blank control (without enzyme solution), negative control (without inhibitor) and positive control (with acarbose as inhibitor). The inhibition rate was calculated according to the following formula [11].

$$
\text { Inhibition rate }(\%)=\frac{\mathrm{A}-\mathrm{B}}{\mathrm{A}} \times 100 \%
$$

A-PNP (p-nitrophenol) concentration in the sample group (subtracting the corresponding blank), Concentration of PNP (p-nitrophenol) in B-negative control (subtract the corresponding blank).

\subsection{The optimal conditions of the $\alpha$-glucosidase action}

\subsubsection{Effect of reaction time on enzyme activity}

$100 \mu \mathrm{L}$ of $30000 \mathrm{U} / \mathrm{L}$ enzyme solution was added to $200 \mu \mathrm{L}$ of phosphate buffer solution and $75 \mathrm{~mol} / \mathrm{LPNPG}$ was used as a substrate, followed by a water bath at $45^{\circ} \mathrm{C}$ for $20,25,30,35,40,45,50$, respectively. $55 \mathrm{~min} .100$ $\mu \mathrm{L}$ of $1 \mathrm{~mol} / \mathrm{L}$ sodium carbonate solution was added to terminate the reaction and the OD values were determined.

\subsubsection{Effect of reaction temperature on enzyme activity}

$100 \mu \mathrm{L}$ of $30000 \mathrm{U} / \mathrm{L}$ enzyme solution was added to $200 \mu \mathrm{L}$ of phosphate buffer solution with $75 \mathrm{~mol} / \mathrm{LPNPG}$ as substrate at $34^{\circ} \mathrm{C}, 37^{\circ} \mathrm{C}, 40^{\circ} \mathrm{C}, 43^{\circ} \mathrm{C}$, 
$46^{\circ} \mathrm{C}, 49^{\circ} \mathrm{C}, 52^{\circ} \mathrm{C}, 55^{\circ} \mathrm{C}$ for $1 \mathrm{~h}, 100 \mu \mathrm{L}$ of $1 \mathrm{~mol} / \mathrm{L}$ sodium carbonate solution was added to stop the reaction, and the OD was measured at $405 \mathrm{~nm}$.

\subsubsection{Effect of substrate concentration on enzyme activity}

$100 \mu \mathrm{L}$ of $30000 \mathrm{U} / \mathrm{L}$ enzyme solution and $0.0156,0.0311,0.0467,0.0623$, $0.0778,0.0934,0.1089,0.1245 \mathrm{~mol} / \mathrm{L}$ other different concentrations of PNPG were respectively added to $200 \mu \mathrm{L}$ of phosphate buffer solution and reacted at $49^{\circ} \mathrm{C}$ for $1 \mathrm{~h}$, adding $1 \mathrm{~mol}$. The absorbance at $405 \mathrm{~nm}$ was measured after stopping the reaction with $100 \mu \mathrm{L}$ of $1 \mathrm{~mol} / \mathrm{L}$ sodium carbonate solution

\subsubsection{Buffer pH Effect on Enzyme Activity}

$100 \mu \mathrm{L}$ of $30000 \mathrm{U} / \mathrm{L}$ enzyme solution was reacted with $75 \mathrm{~mol} / \mathrm{LPNPG}$ and $49^{\circ} \mathrm{C}$ for $1 \mathrm{~h}$ in buffers of different pHs $4,5,5.8,6,6.5,6.8,7.4$ and 8 . The absorbance was measured at $405 \mathrm{~nm}$ after termination of the reaction by $100 \mu \mathrm{L}$ of $1 \mathrm{~mol} / \mathrm{L}$ sodium carbonate solution.

\subsection{Preparation of $\alpha$-glucosidase standard curve}

Under the condition of no inhibitor, the absorbance value (OD) of the enzyme solution at $405 \mathrm{~nm}$ at the concentration of $0,40,60$ and $80,100,120,140 \mathrm{U} . \mathrm{L}^{-1}$ was determined respectively under the "2.1" method. According to the corresponding OD values at different concentrations (C), the standard curve is plotted. The regression equation is:

\section{$Y=1.8709 X-0.001 R^{2}=0.998$}

In the determination of $\alpha$-glucosidase inhibitory activity, the reaction time, reaction temperature, substrate concentration, $\mathrm{pH}$, and other conditions were optimized based on the result of "2.2." By measuring the OD value, that was, the output of PNPG, the OD value was found to vary. The amount of $\alpha$-glucosidase changed and showed the activity of $\alpha$-glucosidase. A good linear relationship appeared between 0 and $140 \mathrm{U} \cdot \mathrm{L}^{-1}$.

\subsection{Determination of Reversible and Irreversible Types of Enzyme Inhibition by Lentinan}

To determine whether the type of enzyme inhibition is reversible or not, the enzyme inhibition kinetics can be used in addition to the removal of inhibitors by physical methods such as dialysis, ultrafiltration or gel filtration. In the experiment, enzyme inhibitors go out and the reaction can be carried out smoothly, which proves to be reversible inhibition, and conversely, irreversible inhibition.

The reaction rate with lentinan $(\mathrm{C}=2 \mathrm{~g} / \mathrm{L})$ was measured under enzyme amounts of $0,10,20,30,40$, and $50 \mu \mathrm{L}$ [12].

\subsection{Determination of the Inhibitory Effect of Lentinan on $\alpha$ - glucosidase}

The substrate concentration was $124.320 \times 10^{3} \mathrm{~mol} / \mathrm{L}$, which was diluted to 4 different concentrations of 1:5, 1:10,1:15, 1:20, in other words, $24.864 \times 10^{3} \mathrm{~mol} / \mathrm{L}, \quad 12.432 \times 10^{3} \quad \mathrm{~mol}, 8.288 \times 10^{3}$ $\mathrm{mol} / \mathrm{L}, 6.216 \times 10^{3} \mathrm{~mol} / \mathrm{L}$. These crude polysaccharides with the concentrations of $25 \mathrm{mg} / \mathrm{L}, 50 \mathrm{mg} / \mathrm{L}$ and $100 \mathrm{mg} / \mathrm{L}$ were used to determine the reaction rate. According to the Lineweaver-Burk plot method, the kinetic curve of the inhibitory effect of the crude polysaccharide of Lentinula edodes was drawn [13].

\section{RESULTS AND DISCUSSION}

\subsection{Effect of reaction time on enzyme}

The experimental results in Figure 1(a) indicate that with the increase of reaction time, the inhibitory effect increases, and the inhibitory activity within 100-120 $\mathrm{min}$ is larger. The longer the reaction time may be, the more fully the enzyme binds to the substrate, and the inhibitory activity gradually increases. Due to the time limited, $120 \mathrm{~min}$ was chosen as the best time condition.

\subsection{The effect of temperature on the enzyme}

The experimental results in Figure 1(b) indicated that when $100 \mu \mathrm{L}$ of $30000 \mathrm{U} / \mathrm{L}$ enzyme solution was based on $0.1245 \mathrm{~mol} / \mathrm{L}$ PNPG, the absorbance at $50^{\circ} \mathrm{C}$ was the maximum. It may be that the temperature continued to rise, which changed the structure of the enzyme, and made it difficult to combine the enzyme with the inhibitor.

\subsection{The effect of substrate concentration on the enzyme}

The experimental results in Figure 1(c)indicated that as the substrate concentration increased from 0.0156 to $0.1089 \mathrm{~mol} / \mathrm{L}$, the absorbance also increased rapidly. When the substrate concentration reached 0.1089 $\mathrm{mol} / \mathrm{L}$ or more, the increase of absorbency is slowed down, which may be when the concentration reaches at $0.1089 \mathrm{~mol} / \mathrm{L}$, the binding of the enzyme will become saturated, and the increase of the substrate has no significant effect on the whole.

\section{4 pH Effect on Enzymes}

The experimental results in Figure 1(d) indicated that when the $\mathrm{pH}$ was $5.0-6.5$, the absorbance was large, and when the $\mathrm{pH} 6.0$ was the optimum $\mathrm{pH}$ and acidic for the highest absorbance. Absorbance values at $\mathrm{pH}<5.0$ or $\mathrm{pH}>6.5$ were significantly reduced, and the active center group of the enzyme may be change due to the $\mathrm{pH}$ too high or too low.

Through different reaction time, temperature, concentration and $\mathrm{pH}$, the enzyme inhibitory effect of lentinan was measured. It was found that the polysaccharide has the strongest inhibitory effect on $\alpha$-glucosidase when the sample concentration was $1 \mathrm{~g} / \mathrm{L}$, the reaction time was $120 \mathrm{~min}$, the temperature was $50^{\circ} \mathrm{C}$, the substrate concentration was $0.1089 \mathrm{~mol} / \mathrm{L}$ and the $\mathrm{pH}$ was 5.0-6.5.
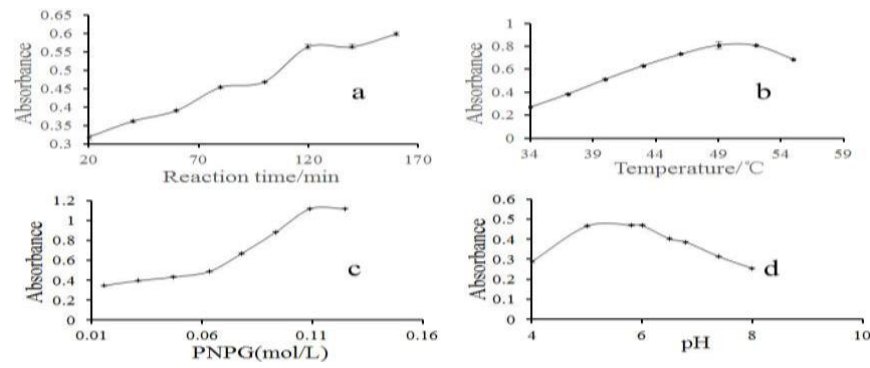

Figure 1: Effect of time, temperature, substrate concentration, $\mathrm{pH}$ on $\alpha$ glucosidase activity

\subsection{Inhibitory effect of lentinan on $\alpha$-glucosidase}

Acarbose as a new oral hypoglycemic agent, has an obvious inhibitory effect on alpha glucosidase. The inhibition rate increased with the increase of acarbose concentration, and the inhibition rate could reach $77.63 \%$ when the concentration was $1 \mathrm{~g} / \mathrm{L}$, from Figure 2. From Figure 1, By measuring the inhibitory effect of polysaccharides on the enzyme at different concentrations, reaction times, $\mathrm{pH}$ and temperature, it was found that when the sample concentration was $1 \mathrm{~g} / \mathrm{L}$, the reaction time was 120 min, and the $\mathrm{pH}$ was $6.0,50^{\circ} \mathrm{C}$, the polysaccharides were reacted with $\alpha$ glucoside.

The enzyme had the strongest inhibitory effect and the inhibition rate was $31 \%$. The positive drug acarbose inhibited the enzyme by $77.63 \%$. It can be seen that the inhibitory activity of lentinan on $\alpha$-glucosidase is far inferior to that of acarbose. However, the sources of mushrooms are wide and their prices are relatively low, which still has some research value. According to the "2.1" method under the determination of different addition of lentinan inhibition of $\alpha$-glucosidase activity as shown in Figure 2(a) below.

\subsection{The reversible and irreversible type of lentinan inhibits $\alpha$ - glucosidase}

The experimental results of the reversible and irreversible types of $\alpha$ glucosidase inhibition by lentinan in Figure 2(b) could be seen that when the amount of enzyme added was $0 \mathrm{~g} / \mathrm{L}$, the reaction proceeded normally, so that the type of inhibition of lentinan was reversible $[12,13]$.

\subsection{Effect of lentinan on $\alpha$-glucosidase inhibition}

The reversible inhibition of the enzyme includes competitive inhibition, non-competitive inhibition and anti-competitive inhibition. Competitive inhibition is that inhibitors compete with the substrate for binding to the same active site of the enzyme, thereby interfering with the binding of the enzyme to the substrate and reducing the catalytic activity of the enzyme. Non-competitive inhibition is that inhibitors can bind to free enzymes as well as to ES complexes, reducing the catalytic activity of the enzyme; anticompetitive inhibition is that inhibitors cannot bind to free enzymes but bind to ES complexes and prevent product formation to reduce the catalytic activity of the enzyme. The experimental results of the type of inhibition of $\alpha$-glucosidase by lentinan were shown in Figure 2(c) below. 
By $1 / \mathrm{S}$ as the abscissa and $1 / \mathrm{V}$ as the ordinate, the double reciprocal plot (see Figure 2(c)) showed that lentinan was a typical Michelle enzyme. With the increase of enzyme concentration, the inhibitory effect of lentinan also increased. Therefore, the type of inhibition of lentinan was competitive inhibition.

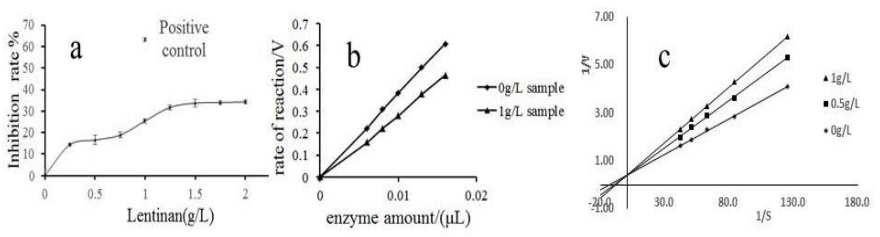

Figure 2: Effects of Different Addition of Lentinan on $\alpha$-glucosidase Activity(a) Determination of reversible and irreversible inhibition of $\alpha$ glucosidase by lentinan(b) Determination of Inhibition Type of Lentinan on $\alpha$-glucosidase(c)

\section{CONCLUSION}

In this experiment, PNPG was used as the substrate, and UV-visible spectrophotometer was used to quantitatively analyze the PNP of the enzymatic hydrolysate. The screening method of $\alpha$-glucosidase inhibitor in vitro was established. The experimental results showed that the optimal reaction conditions of $\alpha$-glucosidase were reaction time $2 \mathrm{~h}$, reaction temperature $50^{\circ} \mathrm{C}$, buffer $\mathrm{pH} 6.0$, concentration of substrate PNPG 0.1089 $\mathrm{mol} / \mathrm{L} .1 \mathrm{~g} / \mathrm{L}$ Lentinan was compared with acarbose and its inhibitory type was studied by double reciprocal mapping. The results showed that the inhibition of $\alpha$-glucosidase by lentinan was a typical type of reversible competitive inhibition kinetics, that lentinan had good inhibitory activity and had potential for development. The extraction and separation process can be systematically studied so that a suitable process route for industrial production can be obtained.

\section{ACKNOWLEDGMENTS}

This study was financed by Jilin provincial development and Reform Commission (Grant No. 2017C044).

\section{REFERENCES}

[1] Dai, R., Liu, R.M., Xiao, J.H. 2015. Research progress on hypoglycemic effect and its mechanism of action of medicinal fungal polysaccharides. China Journal of Chinese Materia Medica, 40 (2), 174179.

[2] Zhou, B., Kong, L., Chen, J. 2009. Study on extraction of pu'er tea polysaccharides and hypoglycemic. Chinese Agricultural Science Bulletin.
[3] Zhong, Y.G., Lin, N., Wang, S.Q., Liu, C.J. 2007. Study on antioxidative and antimicrobial activities of lentinan. Food Science \& Technology.

[4] Ross, K.A., Godfrey, D., Fukumoto, L. 2015. Purification and characterization of water soluble polysaccharides from sweet cherries, raspberries, and ginseng: chemical composition and bioactivity. Research in Health and Nutrition, 3 (4), 1-13.

[5] Wani, B.A., Bodha, R.H., Wani, A.H. 2010. Nutritional and medicinal importance of mushrooms. Journal of Medicinal Plant Research, 4 (24), 2598-2604.

[6] Wang, X.T., Zhu, Z.Y., Zhao, L., Sun, H.Q., Meng, M., Zhang, J.Y. 2016. Structural characterization and inhibition on $\alpha$ - $d$-glucosidase activity of non-starch polysaccharides from fagopyrum tartaricum. Carbohydrate Polymers, 153, 679-685.

[7] Zeng, Y., Guo, F., Chen, Z., Ma, J. 2012. The study on crude polysaccharide of seabuckthorn against activity of $\alpha$-glucosidase and its enzyme kinetics. Chinese Journal of Pharmaceutical Analysis.

[8] Cui, J., Gu, X., Wang, F., Ouyang, J., Wang, J. 2015. Purification and structural characterization of an $\alpha$-glucosidase inhibitory polysaccharide from apricot (armeniaca sibirica l. lam.) pulp. Carbohydrate Polymers, 121, 309-314.

[9] Chen, Z.B., Wan, S.B., Zhu, W.M. 2016. Research progress of natural $\alpha$-glucosidase inhibitors from marine organisms. Chinese Journal of Marine Drugs.

[10] Phan, M.A.T., Wang, J., Tang, J., Yan, Z.L., Ng, K. 2013. Evaluation of $\alpha$-glucosidase inhibition potential of some flavonoids from epimedium brevicornum. LWT - Food Science and Technology, 53 (2), 492-498.

[11] Wang, Q. 2011. Continuous extraction of saponin and polysaccharide from momordica charantia l. and their inhibitory effect on $\alpha$-glucosidase. Scientia Agricultura Sinica.

[12] Pei, L.I. 2016. Study on inhibition kinetics of polysaccharide from yam on $\alpha$-glucosidase. Food \& Machinery.

[13] Zhu, X., Ye, X., Yuan, L., Ding, Y., Zhang, B., Li, X. 2012. Synthesis and hypoglycemic activity evaluation of 7-alkoxyl-rhein. Medicinal Chemistry Research, 21 (4), 421-427.

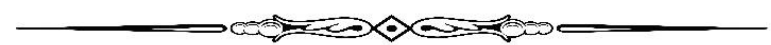

